\title{
HOMLOKZATI ÁRNYÉKOLÓK
}

\section{AKUSZTIKAI CÉLÚ FEJLESZTÉSE}

\section{Az Épületakusztikai Laboratórium kutatásáról}

A homlokzati árnyékolók alapvetően a napsütés túlzott (fel)melegitő hatása elleni védelem céljából létesülnek, azonban hasznos szolgálatot tehetnek külső zaj elleni passzív akusztikai védelem esetében is. Mindkét területre sok cég gyárt termékeket, azonban mindkét célra alkalmas termék jellemzően nem kapható a piacon. A cikk célja egy erre irányuló kutatás eredményeinek bemutatása.

A BME Épületakusztikai Laboratórium egy magyar árnyékolástechnikai céggel 2017-ben közös kutatási projektbe kezdett, melynek célja olyan árnyékolószerkezet kifejlesztése volt, amely a napsütés elleni védelem mellett akusztikai (zajcsökkentési, hangszigetelési) funkciót is ellát.

A kutatás során elemeztük az árnyékolók nappali és éjszakai időszakban való alkalmazási lehetőségeit és előnyeit nyitott lamellák és zárt ablak (nappali időszakban való használat esetére), zárt lamellák és zárt ablak, (éjszakai időszak esetére), zárt lamellák és nyitott ablak esetére, illetve nappali időszakra (nyitott lamellák és nyitott ablak), intenzív szellőztetési igény idején elérhető előnyök vizsgálatára. A cikk részletesen bemutatja és elemzi a kutatási eredményeket.

A szerkezetfejlesztési céllal készült kutatás koncepciójának kidolgozása az árnyékolástechnikai vállalat vezetőjének, Gosztonyi Miklósnak és kollégájának, Ungvári Ferencnek az érdeme, a témavezető a laboratórium vezetője, Nagy Attila Balázs volt. Jelen cikk a hivatkozott tanulmányok alapján készült.

\section{Bevezetés}

Árnyékolásnak nevezzük a napsugárzás teljes vagy részleges távol tartását, kívánt mértékű korlátozását egy adott pontra vagy felületre vonatkozóan. A jó árnyékoló a nap hőenergiájából a lehető legkevesebbet engedi át, annak minél nagyobb részét visszaveri, önmaga kevés energiát nyel el, és az elnyelt energiát kifelé sugározza le, ugyanakkor nem akadályozza a természetes megvilágítást. Általában az a kedvező, ha az árnyékoló tömege kicsi, így a besugárzásos időszakban rá eső energia kis részét nyeli csak el és kevés hőt sugároz vissza a környe- zete felé. Az árnyékolók kialakításánál ügyelni kell arra, hogy kellőképpen át tudjanak szellőzni. Az átszellőzés már a besugárzás időszakában csökkenti a szerkezet melegedését, de fontos a sugárzásmentes időszakban is, mert ennek révén az energia a védett felületektől távol tartható, a benne tárolt hőt tervezetten jól szállítja el.

A fenti szerkezeti követelmények a hanggátlás-hangszigetelés követelményeinek részben ellentmondanak. Az eredményes hanggátláshoz, ill. a hanggátlás javításához megfelelő tömegű, homogén (üregmentes), nehéz, ún. „tömegszerkezet”, vagy vékony, de nagy tömegü, lemezjellegű szerkezet ideális. Mindkét esetben fontos, hogy a szerkezet légzáró, tömített legyen. A hang visszaverődésének mérséklésére hangelnyelő tulajdonságú kialakítás szükséges, amely gyakran porózus anyagszerkezettel, illetve nem sík, hanem megtört vonalú felülettel érhető el. Fontos még egy szerkezeti elemet kiemelni: az árnyékoló és a hátszerkezet közvetlen szerkezeti kapcsolatát (rögzítés), mert a szerkezetek képesek rezgést átadni egymásnak, ami az akusztikai jellemzőket leronthatja.

A jellemző használati módok figyelembevételével további ellentmondások merülnek fel az árnyékolás és zajcsökkentés támasztotta igények között. A nappali időszakban többnyire zárt nyílászáró előtt elhelyezkedő, valamely mértékben nyitott árnyékoló használata jellemző, mely így óv a túlzott felmelegedéstől, de a fény bejutása is biztosított. Éjszakai időszakban, pl. lakóépületek esetében jellemző használati mód a nyitott nyílászáró előtt elhelyezkedő árnyékoló, mely esetben a fény kizárása mellett igény a belső tér szellőzése is. E helyzetekben a többi követelmény miatt az árnyékoló zajcsökkentőhangszigetelő hatása kevésbé tud érvényesülni.

Az ellentmondó követelmények miatt az épületek akusztikai védelmében is szerepet betöltő árnyékolószerkezet kifejlesztése összetett feladat. [3],[4] Először az árnyékolószerkezetek jellemző alkalmazási helyzetekben lehetséges akusztikai hatásait kell tisztázni. 


\section{Árnyékolószerkezetek lehetséges akusztikai hatása}

A homlokzati szerkezetek legfontosabb akusztikai feladata az épület belső helyiségeinek az épület külső oldalát érő zaj elleni védelme. A zaj az emberek közérzetére, tevékenységeire és egészségére is kedvezőtlen hatással lehet, amely a zaj mértékétől és jellegétől függően például halláskárosodásban, egészségügyi problémákban, teljesítménycsökkenésben és kellemetlen komfortérzetben is megnyilvánulhat. A hazai szabályozás korlátozza az épületbe jutó zaj mértékét. A helyiségeken belüli zajhatárértékek egészségügyi megfontoláson alapulnak: a nappali időszakban a kommunikáció zavarásának, az éjszakai időszakban a pihenés zavarásának elkerülése a cél. A követelményértékek nem a zaj maximális szintjét, hanem annak egy adott időre vonatkoztatott időbeli átlagát korlátozzák.

A homlokzati szerkezetek hangszigetelés-méretezésének célja, hogy a helyiségbe bejutó - elsősorban közúti közlekedési - zajt korlátozza. A közlekedési zaj ellen védendő helyiség homlokzati szerkezeteit úgy kell kiválasztani és összeépíteni, hogy azok eredő zajcsökkentő hatása révén a zaj ellen védendő helyiségbe bejutó közlekedési zaj a szükséges mértékig csökkenjen. A homlokzat hangszigetelését az MSZ 15601-2 szabvány alapján kell méretezni, melyben a főbb kiinduló adatok a homlokzat mértékadó zajterhelése, a helyiség rendeltetésétől függő zajhatárérték, valamint a helyiség geometriai és teremakusztikai jellemzői.

A homlokzati szerkezetek akusztikai termékjellemzője általános esetben a súlyozott léghanggátlási szám és a zajterhelés jellege alapján meghatározott színképillesztési tényező összege $\left(\mathrm{R}_{w}+\mathrm{C}_{\mathrm{tr}}, \mathrm{dB}\right)$. A burkolatjellegű szerkezetek hangszigetelési termékjellemzője a súlyozott léghanggátlási számjavítás és a zajterhelés jellege alapján meghatározott színképillesztési tényező összege $\left(\Delta \mathrm{R}_{\mathrm{w}}+\mathrm{C}_{\mathrm{tr}}, \mathrm{dB}\right)$. A fenti jellemzők meghatározása az MSZ EN ISO 10140 szabványsorozat alapján szabványos laboratóriumi méréssel történik.

Árnyékolószerkezetek esetében a figyelembe vehető akusztikai termékjellemző meghatározása önmagában is problémás lehet. Ennek megértéséhez meg kell vizsgálni, hogy az árnyékolószerkezetek alkalmazása milyen használati módokkal történhet. A háttérszerkezettől függően két alapállapot fordulhat elö, amely az árnyékoló zárt vagy nyitott állapotától függően tovább bontható:

\section{Alkalmazás háttérszerkezet nélkül (nyitott nyilászáró elött)}

Amennyiben az árnyékoló mögött nyitott helyzetű a nyílászáró, úgy a kültéri árnyékoló akusztikai szerepe fokozott, hiszen az ablak hanggátló hatása nyitott állapotában szinte teljesen megszünik.
Ha az árnyékoló felülete csukott (pl. táblás árnyékoló vagy összezárt lamellák esetén) és a pereme mentén is tömített, akkor a helyiség nem szellőzik, a fény bejutása korlátozott. Ilyenkor az árnyékoló akusztikai hatása leginkább hanggátlásjellegű.

Ha az árnyékoló felülete valamely fokban nyitott (pl. forgatható vagy fix) lamellákból áll, akkor a helyiség szellőzése és fény bejutása is biztosított, a levegó és a benne terjedő hang át tud jutni az árnyékolón keresztül a belső térbe. Ez esetben az árnyékoló akusztikai akadályt jelent, hatását inkább zajcsillapításnak vagy zajárnyékolásnak nevezhetjük.

Ilyen használati mód esetében felmerülhet még az árnyékolószerkezet hangelnyelő hatása is, mely nyitott ablak mellett a belső oldalon érvényesülve a helyiség teremakusztikai jellemzőit (pl. utózengési idő), külső oldalon érvényesülve a szomszédos épületekre jutó zajterhelést csökkentheti.

\section{Alkalmazás háttérszerkezettel (zárt nyilászáró előtt)}

Amennyiben az árnyékolószerkezetek mögött csukott nyílászáró szerkezet található, e szerkezet feladata a megfelelő hő- és hangszigetelés biztosítása. A külső árnyékoló akusztikai hatása az ablak hanggátlásának növelése, azaz a belső térbe jutó zaj csökkentése.

Zárt lamellák esetében, amennyiben az árnyékoló pereme is megfelelően tömített, a helyiség nem szellőzik, a fény bejutása korlátozott, az árnyékolószerkezet akusztikai hatása léghangszigetelés-javítás jellegű. A hanggátlás javitó hatás meghatározásakor a viszonyítási alap az alapszerkezet hanggátlása. Árnyékolószerkezetek vizsgálata esetében azonban nem életszerú a burkolatok javító hatásának szabványos vizsgálatakor használt, nagy fajlagos tömegű falazott szerkezet alkalmazása, hiszen az árnyékolók használata mögöttes nyílászáró szerkezettel és nem falazattal történik.

Valamely fokban nyitott lamellák esetében a szellőzés és fény bejutása is biztosított, a levegó és a benne terjedő hang át tud jutni az árnyékolón keresztül a belső térbe, az árnyékoló akusztikai hatása a zajcsökkentéssel jellemezheto".

Csukott nyílászáró előtt történő használati mód esetében is felmerülhet az árnyékolószerkezet hangelnyelő hatása, mely a zárt nyílászáró miatt csak a külső oldalon érvényesülhet, így a szomszédos épületekre jutó zajterhelést csökkentheti. Belső oldali árnyékoló hangelnyelő kialakítása a beltér teremakusztikai jellemzőit (pl. utózengési idő) befolyásolhatja. Az 1. táblázat az árnyékolószerkezetek alkalmazási lehetőségeit és akusztikai hatásait foglalja össze. 
1. táblázat. Az árnyékolók alkalmazása során előforduló négy alapállapot

\begin{tabular}{|c|c|c|c|c|}
\hline állapot sorszáma & 1. & 2. & 3. & 4. \\
\hline $\begin{array}{l}\text { beállitás sematikus } \\
\text { rajza }\end{array}$ & & & X & - X \\
\hline lamellák állapota & zárva & nyitva & zárva & nyitva \\
\hline ablak állapota & csukva & csukva & nyitva & nyitva \\
\hline árnyékolás & ++ & + & ++ & + \\
\hline szellözés & + & ++ & + & ++ \\
\hline $\begin{array}{l}\text { akusztikai elsődleges } \\
\text { hatás }\end{array}$ & $\begin{array}{l}\text { hangszigetelés- } \\
\text { javitás }\end{array}$ & nincs? & hangszigetelés & zajcsökkentés \\
\hline egyéb akusztikai hatás & $\begin{array}{l}\text { hangelnyelés } \\
\text { kültér felé }\end{array}$ & $\begin{array}{l}\text { mérsékelt } \\
\text { zajcsökkentés }\end{array}$ & $\begin{array}{l}\text { hangelnyelés } \\
\text { kültér és beltér } \\
\text { felé }\end{array}$ & \\
\hline
\end{tabular}

A cég meglévő termékkínálatának laboratóriumi és helyszíni vizsgálata

Az előzetes tanulmányok [1] alapján szúkítettük a lehetséges szerkezetek és akusztikai hatások körét. A vizsgálatok során kizárólag külső oldali árnyékolószerkezeteket vizsgáltunk. A lehetséges akusztikai hatások közül a hanggátló, hangszigetelést javító, ill. zajcsökkentő hatásokat vizsgáltuk. Az esetleges hangelnyelő hatással a kutatás további részében nem foglalkoztunk.

A laboratóriumi vizsgálatok során az ún. súlyozott léghanggátlási számot $\left(\mathrm{R}_{w}, \mathrm{~dB}\right)$ határoztuk meg. E jellemző termékadatot, információt nyújt az adott építés termék, jelen esetben egy árnyékolóelem, illetve a két szerkezet egyidejű alkalmazásával elérhető hangszigetelés mértékéről. Fizikai tartalma a két szomszédos tér átlagos hangnyomásszint-különbsége, melynél figyelembe veszik az árnyékoló, az ablak (a hangenergia közvetítő felülete) nagyságát és a zajjal terhelt tér (laboratórium) utózengési idejét is.

A helyszíni vizsgálatok során a súlyozott léghanggátlási szám helyett az ún. súlyozott hangnyomásszintkülönbség $\left(D_{\mathrm{nT}, w}, \mathrm{~dB}\right)$ jellemzőt határoztunk meg. A súlyozott léghanggátlási szám jellemző meghatározásához hasonlóan ebben az esetben is hangnyomásszint-különbséget határozunk meg, de a módosító tényezőknél nem vesszük figyelembe a hangenergia-közvetítő felület nagyságát, csak a zaj ellen védett tér hangelnyelését jellemző utózengési idejét. A fizikai tartalom másik eleme az, hogy ilyen esetben a terek hangnyomásszint-eloszlása eltér egymástól, és a laboratóriumi körülményektől is Helyszíni mérések alkalmával a zaj ellen védett tér sokkal több hangelnyelő felületet tartalmaz a diffúz téri laboratóriumhoz képest, a zajterhelést közvetíto külső térrel kapcsolatban pedig nem is lehet hangenergia-eloszlásról beszélni. Ezért ilyenkor a homlokzat előtt 2 m-re lévő pontban kialakuló hangnyomásszintet veszik alapul a különbség meghatározásához.

A vizsgálatok során meghatároztuk az un. színképillesztési tényezőket $\left(\mathrm{C}, \mathrm{C}_{\mathrm{tr}}, \mathrm{dB}\right)$ is. E korrekciós tényező azért szükséges, mert a szerkezetekre beeső egyes zajok frekvenciamenete eltéró, az épületen belüli zajokkal öszszehasonlítva a közlekedési zaj több kis frekvenciás (mély hangok tartománya) összetevőt tartalmaz, amelyek szubjektíven nagyobb mértékben zavaró hatásúak.

Az árnyékolók hanggátlásjavító hatásának vizsgálatához olyan alapszerkezetet alkalmaztunk, mely a mai höszigetelési követelmények alapján korszerú szerkezetnek tekinthető, ill. alkalmazása széles körben elterjedt. Így alapszerkezetként egy 4-12-4-12-4 üvegezésű, fém tokés szárnyszerkezetű nyílászáró szolgált, melynek beépítése a követelményeknek megfelelően a belső oldalon lég- és párazáró szalaggal, a külső oldalon szél- és vízzáró szalaggal történt.

A meglévo" termékek laboratóriumi és helyszíni vizsgálatai alapján a szerkezeteket múködésük és akusztikai hatásuk alapján négy csoportba soroltuk:

A 80-90 mm széles kis tömegű lamellákból álló zsaluziaszerkezetek kis tömegúek, zárt állapotban a nyílászáró síkja előtt kb. 50 mm-re helyezkednek el, a laboratóriumi vizsgálatok szerint a nyílászáró hangszigetelését $800 \mathrm{~Hz}$ alatt egyáltalán nem, fölötte kismértékben javítják. A közlekedési zajokkal szemben kis- és közepes frekvenciatartományban van szükség hanggátlásjavításra, így ezen termékek további vizsgálata indokolatlannak bizonyult.

A kislamellás szerkezetek a zsaluziaszerkezeteknél némileg nagyobb tömegú és merevebb, 55-90 mm széles lamellákkal készülnek, a nyílászáró síkja elé általában 100-150 mm-re építik be őket. A sínes megvezetésű elemek záródása a zsaluziákhoz képest kedvezőbb. A vizs- 
gálati eredmények szerint az ablaktól minél távolabb, a falsík előtt elhelyezett kislamellás árnyékolók már a 400 Hz feletti tartományban is mutatnak - azonban csak kismértékű - hangszigetelést javító hatást. A közlekedési zajok fent említett jellegzetességei miatt ezek alkalmazásával sincs reális lehetőség érdemi hangszigetelést javitó hatást elérni.

A nagylamellás szerkezetek az előzőekhez képest nagyobb tömegű lamellákkal rendelkeznek, amelyek kb.

250 mm szélességűek, zárt állapotban a nyílászáró síkja előtt kb. 150-220 mm-re helyezkednek el. A vizsgálat során az elemek záródása az előző csoportnál gyengébben valósult meg. A legtöbb ilyen árnyékoló a nyílászárószerkezet hangszigetelését kb. $400 \mathrm{~Hz}$ fölött kismértékben javítja, míg az egyik szerkezet esetében csak zaj elleni védelem szempontjából már indifferens $4000 \mathrm{~Hz}$ frekvenciatartomány felett volt kimutatható eredmény. Az árnyékolók rezonanciahatása miatt a kb. $630 \mathrm{~Hz}$, 1600 Hz és 3150 Hz frekvenciákon a hanggátlásjavító görbék jelentős visszaesése tapasztalható.

A táblás szerkezet(ek) jelentősebb tömeggel rendelkező, lamella nélküli tömör árnyékolószerkezet. A vizsgálat során a nyílászáró síkja előtt kb. 150 mm-re helyezkedett el. A szerkezeti sajátosságok alapján meghatározott rezonanciafrekvencia $30 \mathrm{~Hz}$-nél alacsonyabb. E rezonanciafrekvencia fölött a szerkezet hanggátlást javító hatást mutat. 800 Hz-en jelentős visszaesés tapasztalható, mely jelenség a táblalemez (vastagságából és fajlagos tömegéből adódó) határfrekvenciája miatt jelentkezik.

\section{Fejlesztési lehetőségek}

A meglévő termékek laboratóriumi és helyszíni vizsgálatai és elméleti megfontolások alapján az akusztikai minőség javítására a következő módosítási lehetőségeket állapítottuk meg:

\section{Hanggátlásjavítás $(\Delta \mathbf{R})$}

Az árnyékoló hanggátlásának növelése az ablak mindhárom használati állapotában előnyös lehet. Jelentős hanggátlás-növekedés azonban csak akkor várható, ha az árnyékoló élei és a homlokzat közötti rést lezárjuk, az árnyékoló légzárását jelentősen növeljük, vagy az élek mentén labirintus kialakítású hang(zaj)csillapítóval lehet a szellőzést biztosítani.

A hanggátlásjavítás fokozása a következő beavatkozásokkal lehetséges:

IA lamellák tömegének és merevségének növelése: a tömeg növelésével nő a hanggátlás.

I A lamellacsatlakozások résein kialakuló levegőáram csökkentése: a léghanggátlás alapvető követelménye a rések jelentős csökkentése.

IÁrnyékoló és homlokzati fal, illetve káva közötti ré- sek csökkentése: az árnyékolót megkerülő hangút lezárásával lehetséges.

\section{Hangcsillapítás-növelés ( $\Delta D)$}

A hang(zaj)csillapító hatás elsősorban az ablakok nyitott és résnyire nyitott állapotában (szellőzóállásban) játszik szerepet, de megfelelő mértékű hang(zaj)csillapító esetén a zárt nyílászáró relatív magas léghanggátlása ellenére is mérheto", érzékelhető lehet.

A hangcsillapítás növelése a következő beavatkozásokkal lehetséges:

I Az árnyékoló ablak felé eső oldalának hangelnyelő tulajdonságúvá alakítása (pl. a belső oldal perforálásával, a lamellákban hangelnyelő réteg elhelyezésével): ezzel az árnyékolón átjutó, az árnyékoló és az ablaküveg között visszaverődő zaj csillapítható, és csökkenthető a légtérben kialakuló rezonanciahatása is.

I Lamellák labirintusszerü (pl. Z, vagy dupla Z formájú) kiképzése, és a lamellák egyik oldalának hangelnyelő tulajdonságúvá alakítása: így a lamellák között „átáramló" zaj a hangelnyelés révén csillapítható.

ı Káván kívüli árnyékoló esetén az árnyékoló ablaknyíláson való túlnyúlásának növelése: ezzel az árnyékolót megkerülő hangút csillapításának növelése érhető el (amennyiben az előző pontban felsorolt, légtömör élzáródás biztosítása nem oldható meg).

I A lamellák belső oldalának perforációja kialakítható makro- és mikroperforálással (amennyiben a lyukak átméröje 1 mm-nél kisebb). A mikroperforált lemezek akusztikai működési mechanizmusa eltérő, ezért ezeket később érdemes részletesebben megvizsgálni. A perforációk mögötti üregekkel rezonátorhatás (negyedhullámos rezonátor, Helmholtz-rezonátor) is elérhető, ezzel hangolható a megvalósuló hangelnyelés is. Igaz, a jellemző lamellaméretek miatt a rezonanciafrekvencia (ahol a maximális hangelnyelést lehet elérni) jellemzően a magasabb, 1 kHz és e fölötti frekvenciatartományban várható.

\section{Árnyékoló keltette rezonanciák hatásának csökkentése}

A vizsgálati eredmények elemzésénél is találkoztunk olyan jelenséggel, amely szerkezeti rezonanciák jelenlétére utal. A rezonanciák hatására a homlokzat eredeti léghanggátlásához képest alacsonyabb hanggátlás is kialakulhat, és csökkenhet az árnyékoló saját hanggátlásjavító hatása is.

A szerkezeti rezonanciák csökkentése a következő beavatkozásokkal lehetséges:

I Az árnyékolók homlokzatra történő rögzítéséből adódó rezonanciák rezgésszigetelt rögzítéssel csökkenthetőek. Az árnyékoló, mint tömeg, a rugószerű rögzítéssel tömeg-rugó rezonanciát alkothat, ami az eredő hanggát- 
lásra negatív hatással lehet. A rögzítőelemek megfelelő kialakításával ez a hatás csökkenthető.

I Az árnyékoló és ablak közötti légtér rezonanciáinak csökkentése. A rezonanciák jellemzően a bezárt légtér mélységi irányában alakulnak ki. Az árnyékoló belső felületének hangelnyelő tulajdonságú kiképzésével vagy a kávában elhelyezett hangelnyelő anyaggal csökkenthető.

I Az árnyékoló egyes elemein belül (pl. szendvicsszerkezetú táblás árnyékolóban, nagylamellás árnyékoló lamelláiban) kialakuló rezonanciák csökkentése. Belső vázstruktúrával és - elsősorban - hangelnyelő tulajdonságú kitöltőanyaggal valósítható meg.

Annak ellenére, hogy a módosítási lehetőségek árnyékolócsaládonként hasonlóak, az alábbi táblázatokban minden vizsgált árnyékolót külön szerepeltetünk. Néhány jellemző árnyékolótípus akusztikai jellemzőinek javításához javasolt szerkezeti módosításokat a 2. táblázat foglalja össze.

\section{Fejlesztési megoldások és eredmények}

A laboratóriumi és helyszíni vizsgálatok és elemzések alapján négy új fejlesztésű szerkezet került legyártásra, melyek kialakításakor a korábbi kutatási eredmények tőprofilok biztosítják. A hanggátlást növelő hatást a lamellák tömege és a függőleges állapotukban kialakuló zárt felület adja.

A 2. szerkezet (perforált lamella) 3 oldalán tömör, alsó oldalán perforált lemezből álló, hangelnyelő anyaggal kitöltött, forgatható, függőleges állapotukban zárt felületet alkotó lamellákból áll. A hanggátlást növelő hatását a lamellák tömege, a függőleges lamellaállapotban kialakuló zárt felület, a tömített kapcsolatok és a hangelnyelőbetét eredményezi.

A 3. szerkezet (cikcakk lamella) a 2. szerkezet továbbfejlesztett változata 3 oldalán tömör, belső oldalán perforált lemezből álló, hangelnyelő anyaggal kitöltött, cikcakk alakú, függőleges állapotában zárt felületet alkotó, tömített lamellacsatlakozású árnyékoló. Zárt állapotában az árnyékoló hanggátlást növelő hatását a lamellák tömege és a függőleges lamellaállapotban kialakuló zárt felület adja, amit az ablak felé néző oldal hangelnyelő kialakítása tovább javít.

A 4. szerkezet (zöld lamella) megnövelt vastagságú alumíniumlemezből készített, felső (külső) oldalán szárazságtűrő növényzettel kombinált forgatható lamellákkal, amelyek függőleges állapotukban zárt felületet al-

\section{2. táblázat. Néhány jellemző árnyékolótípus akusztikai jellemzőinek javításához javasolt szerkezeti módosítás}

Jelmagyarázat a 2. táblázathoz: - : nem értelmezhető; + / ++: hatásos vagy nagyon hatásos; 0 : hatástalan

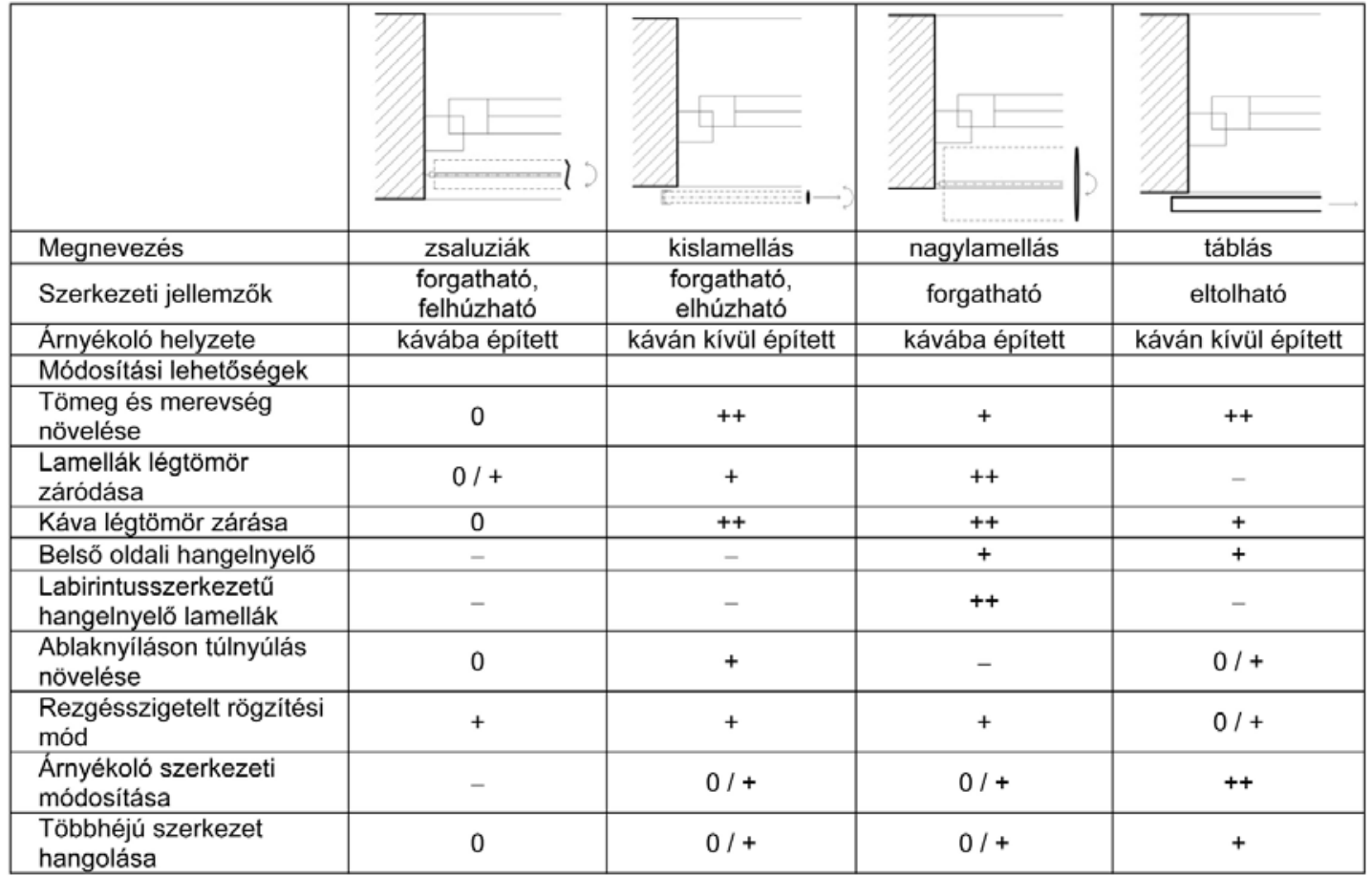

eredményeit figyelembe vettük. E szerkezetek és főbb jellemzőik a következők:

Az 1. szerkezet (fix-forgó lamella) téglalap keresztmetszetű, tömör falú lamellákból áll. A lamellák egyik része fix, vízszintes pozíciójú, minden második lamella pedig forgó: vízszintes állapotból függőleges állapotba fordítható. A forgó lamellák függőleges állapotukban zárt felületet alkotnak, melyek között az élzárást tömí- kotnak, s záródásukat lépcsős élkiképzésbe helyezett, összenyomódó tömítőprofilok biztosítják. A zárt állapotban az ablak felőli oldalán nincs hangelnyelő réteg.

A szerkezetek vizsgálati eredményeit [2] a 3. táblázatban lehet áttekinteni.

A homlokzati hanggátlásvizsgálatoknál alkalmazott, $45^{\circ}$-os zajbeesési szögú vizsgálat mellett a $\mathrm{T}_{0}=0,5 \mathrm{sec}$ utózengési időre vonatkoztatott, a közlekedési zaj szín- 


\begin{tabular}{|c|c|c|c|c|c|}
\hline $\begin{array}{c}\text { Szerkezet } \\
\text { megnevezése }\end{array}$ & Szerkezet ábrája & $\begin{array}{c}\text { Nyílászáró } \\
\text { állapota }\end{array}$ & $\begin{array}{c}\text { Lamellák } \\
\text { helyzete }\end{array}$ & $\mathrm{D}_{\mathrm{w}, \mathrm{ls}, 2 \mathrm{~m}, \mathrm{nT}}$ & $\mathrm{C}_{\mathrm{tr}}$ \\
\hline \multirow{4}{*}{ Fix-forgó lamella } & & \multirow{2}{*}{ nyitva } & nyitva & 11 & -1 \\
\hline & & & zárva & 21 & -1 \\
\hline & & \multirow{2}{*}{ zárva } & nyitva & 41 & -4 \\
\hline & & & zárva & 46 & -5 \\
\hline \multirow{4}{*}{ Perforált lamella } & & \multirow{2}{*}{ nyitva } & nyitva & 12 & 0 \\
\hline & & & zárva & 30 & -2 \\
\hline & & \multirow{2}{*}{ zárva } & nyitva & 44 & -5 \\
\hline & & & zárva & 53 & -4 \\
\hline \multirow{4}{*}{ Cikcakk lamella } & & \multirow{2}{*}{ nyitva } & nyitva & 14 & -1 \\
\hline & & & zárva & 30 & -1 \\
\hline & & \multirow{2}{*}{ zárva } & nyitva & 43 & -5 \\
\hline & & & zárva & 53 & -4 \\
\hline \multirow{4}{*}{ Zöld lamella } & & \multirow{2}{*}{ nyitva } & nyitva & 10 & 0 \\
\hline & & & zárva & 23 & -1 \\
\hline & & \multirow{2}{*}{ zárva } & nyitva & 41 & -5 \\
\hline & & & zárva & 48 & -5 \\
\hline
\end{tabular}

3. táblázat. Fejlesztett árnyékolók helyszíni vizsgálati eredményei

Jelmagyarázat a 3. táblázathoz: $\mathrm{R}_{\mathrm{w}}$ : súlyozott léghanggátlási szám; $\mathrm{D}_{\mathrm{nT}, \mathrm{w}}$ : súlyozott hangnyomásszintkülönbség

$\mathrm{C}_{\mathrm{tr}}$ : színképillesztési tényező. képének figyelembevételével számított hangnyomás-különbség vizsgálati eredmények áttekintése alapján az alábbi megállapítások tehetők:

I zárt lamellaállás mellett a legalacsonyabb hangnyomásszint-különbség értéket a fix-forgó lamellájú szerkezet eredményezte: $D_{\mathrm{w}, \mathrm{nT}}^{\prime}=20 \mathrm{~dB}$ nyitott, és $\mathrm{D}_{\mathrm{w}, \mathrm{nT}}^{\prime}=41$ $\mathrm{dB}$ zárt ablakkal;

I zárt lamellaállás mellett a legmagasabb hangnyomásszint-különbség értékeket a perforált és a cikcakk lamella eredményezte: $\mathrm{D}_{\mathrm{w}, \mathrm{nT}}^{\prime}=28-29 \mathrm{~dB}$ nyitott, és $\mathrm{D}_{\mathrm{w}, \mathrm{nT}}^{\prime}$ = 49-49 dB zárt ablakkal;

I a perforált és a cikcakk lamellák zajcsökkentő hatása között nincs különbség;

I nyitott lamellaállás és nyitott ablak mellett is $\mathrm{D}_{\mathrm{w}, \mathrm{nT}}^{\prime}=$ 10-13 dB hangnyomásszint-különbség állapítható meg,

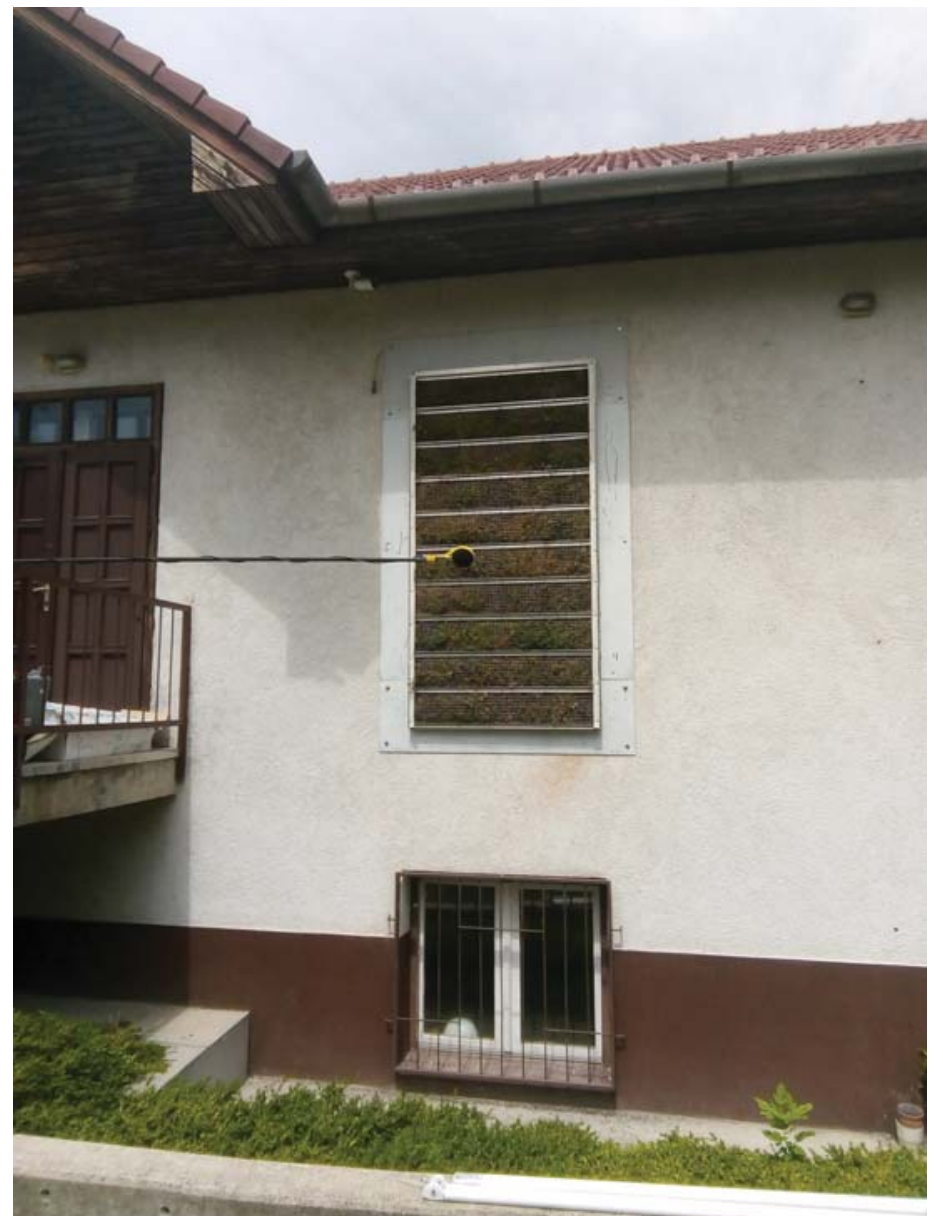

vagyis a nyitott helyzetű árnyékolókkal is érhető el zajcsillapító hatás.

Megállapítható, hogy reális lehetőség mutatkozik a napsugárzás elleni védelmet biztosító árnyékolószerkezeteket egyben hanggátlást növelő szerkezetekként való alkalmazására. Mindeközben - bizonyos korlátok mellett - ez a helyiség szellőztetése idején is jelenthet előnyöket.

\section{Dr. Hunyadi Zoltán, Gosztonyi Miklós, \\ Mesterházy Beáta, Nagy Attila Balázs}

Irodalom / References

[1] Becker, Gábor - Dobszay, Gergely Hunyadi, Zoltán - Mesterházy, Beáta - Nagy, Attila Balázs: „Tanulmány a Krüllung Árnyékolástechnika Kft által gyártott árnyékolószerkezetek akusztikai célú fejlesztési lehetőségeiről", 2019-03-17. [2] Dr. Hunyadi, Zoltán - Mesterházy, Beáta Nagy, Attila Balázs: „Tanulmány a Krüllung Árnyékolástechnika Kft által gyártott árnyékolószerkezetek akusztikai fejlesztése projekt harmadik és negyedik szakaszában végzett helyszíni hanggátlásvizsgálatok eredményéről", 2019-07-15.

[3] Fausti, Patrizio - Secchi, Simone -

Martello, Nicolo Zuccherini: „The use of façade sun shading systems for the reduc tion of indoor and outdoor sound pressure levels", Building Acoustics, Vol 26, Issue 3 (2019), pp 181-206, DO

$<10.1177 / 1351010 \times 19863577>$.

[4] Martello, Nicolo Zuccherini - Fausti, Patrizio-Santoni, Andrea - Secchi, Simone: "The Use of Sound Absorbing Shading Systems for the Attenuation of Noise on Building Façades, An Experimental Investigation", Buildings, 2015, 5, 1346-1360, DOI: $<10.3390 /$ buildings5041346>.

A kutatás a GINOP-2.1.7-15-2016-00593 sz. projekt támogatásával valósult meg. 


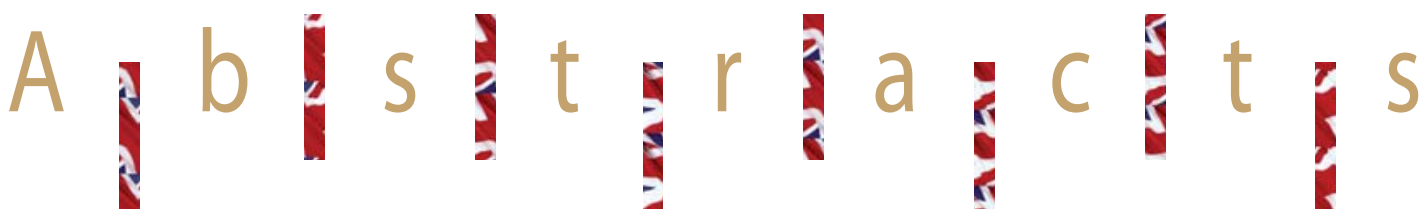

DOBSZAY, Gergely - BAKONYI, Dániel: QUESTIONING BUILDING TECHNOLOGY AND SKYLIGHT INSTALLATION

Citation: Metszet, Vol 10, № 6 (2019), pp 70-73, DOI: 10.33268/Met.2019.6.9

Kits to install top quality skylight systems do not always result in satisfactory results. Too often the location of a roof's structure, tiling battens, the poor use of vapour barriers and insulation materials can lead to failure. Apart from manufacturers' guidelines what other steps should be taken to ensure quality installation? This article examines installation methods, thermal insulation types, waterproofing, vapour barriers and good practice guidelines.

\section{TAKÁCS, Lajos Gábor - JANKUS, Bence: PROBLEMS OF FIRE SPREADING BETWEEN FACADES AND ROOF}

Citation: Metszet, Vol 10, № 6 (2019), pp 74-79, DOl: 10.33268/Met.2019.6.10

A worldwide problem facing the design of buildings is how to prevent the spread of fire from a buildings' elevation into the roof space. Analysis of how the eaves to a building are designed can be critical in preventing loss of lives and extensive damage to a building's fabric. It has been found that not only the use of materials can result in different outcomes, also the geometric arrangement of elements, distance of the eaves from the wall and even the depth at which openings are placed within a wall are all valid factors. The overall aim being to reduce potential for fire to spread by reducing potential for fires to reach uncontrollable temperatures.

\section{KIS, Viktória: COOL FIRE PREVENTION DETAILING AT REBORN OUTPATIENT CARE CENTRE} Citation: Metszet, Vol 10, № 6 (2019), pp 80-85, DOl: 10.33268/Met.2019.6.11 OUTPATIENT BUILDING, KISKUNFÉLEGYHÁZA, HUNGARY ARCHITECT: PÁL BOROS

"The Devil in the Details" resurfaces when designing for fire prevention, especially regarding health care buildings. This refurbishment project posed some unusual, yet relevant to most prefabricated building type, problems. Precast concrete structures, although practical in terms of construction speed, are not best suited in terms of fire safety: edge details and floor to wall junctions are liable to failure. Simply covering these junction in plasterboard can prove satisfactory, but issues of vapour barriers, thermal insulation and installation of improved fenestration must also be met Here fire prevention detailing became the main architectural tool for solv ing all these latter mentioned problems, the result being tantamount to seamless in appearance.

\section{NÉMETH, Csaba: IN THE WAKE OF IGNÁC ALPÁR}

Citation: Metszet, Vol 10, No 6 (2019), pp 86-91, DOl: 10.33268/Met.2019.6.12 RAOUL WALLENBERG HIGH SCHOOL TRANSFORMATION AND EXTENSION BUDAPEST, HUNGARY

ARCHITECTS: CSABA NÉMETH, MÁTYÁS FEHÉR and TIBOR VARGA

The cultural identity of a school often lies partly within its built fabric resulting in the need to approach any works involving demolition, extension and alterations with due care. In one form or another this building complex has served its role in education, even though it has changed hands many times over its history regarding subjects taught there, it has always functioned as a high school. Sadly between 2008 and 2017 the main building was unoccupied, falling into minor disrepair, it now has a new lease of life alongside its complementary new extension block. The key to this project's successful rebirth being a measured respect for history balanced with thoughtful modernisation.

\section{HEGYI, Dezső, KAPOVITS, Géza: ARCHITECT AND ENGINEERING DESIGN WORK IN HARMONY} Citation: Metszet, Vol 10, No 6 (2019), pp 92-97, DOI: 10.33268/Met.2019.6.13 CASE FOR A FOREST VILLA ARCHITECTS: BÁLINT ÁSZTAI and CSABA KOVÁCS

Locating a large villa and its smaller guest house on a graded site amongst trees lead to the development of a project reminiscent of Frank Lloyd Wright's Falling Water. Spaces being accentuated by cantilevered structures that form terraces and roofs. At first this seems a relatively straight forward task, yet on further evaluation complex solutions were required to achieve architectural harmony: engineering being the driving force behind this project's flow from internal to external spaces without need for poorly conceived steps. The resulting building also welcomes nature into its fabric by means of planted terraces and green roofs, contemporary organic.

\section{HEINCZ, Dániel, KAPOVITS, Géza: AT THE LIMITS OF CONTEMPORARY RESIDENTIAL ARCHITECTURE} Citation: Metszet, Vol 10, № 6 (2019), pp 98-103, DOI: 10.33268/Met.2019.6.14 FAMILY HOME, JÁSZBERÉNY, HUNGARY

ARCHITECTS: ÉPITÉSZ STÚDIÓ KFT, ZSOLT FÉLIX and BÁLINT GULYÁS Developing a corner site to accommodate a family home based upon interconnected pavilions, dealing with problems associated to surface water drainage and creation of green roof solutions, required non-standard foundations and waterproofing methods. Aside from the technical achievements a desire for clarity of materials and spatial functions had to be met. The key to success being how to seamlessly integrate architectural, structural and mechanical engineering elements.

\section{HUNYADI, Zoltán - GOSZTONYI, Miklós - MESTERHÁZY, Beáta - NAGY, Attila Balázs: DEVELOPMENT OF WINDOW SHADING DEVICES ACOUSTIC BARRIERS Citation: Metszet, Vol 10, No 6 (2019), pp 104-109, DOI: 10.33268/Met.2019.6.15 Health problems associated with noise disturbance outside buildings can be alleviated with the use of acoustic shielding devices: These usually function in first place as light shading devices, shutters, screens or even planting. The exact type of device used, its installed location and different degrees of permeability can vastly impact effectiveness. Combined with window types results may also vary. Segmented screens, solid screens and various degrees of perforation have been examined also taking into con- sideration the impact regarding natural ventilation.}

